\title{
MENGENAL DEPRESI MENTAL, RESIKO YANG DITIMBULKAN DAN CARA PENANNGULANNYA
}

\author{
Dulhadi
}

\begin{abstract}
Abstrak
Setiap orang memiliki resiko terkena depsresi. Sebagai salah satu gangguan mental, depresi dapat menyerang siapa saja, kapan saja dan dimana saja. Depresi muncul umumnya ketika sang korban tengah berada dalam kegaulauan. Kian sering seseroang mengalami kegalauan, kian besar pula peluang yang bersangkutan terkena depresi. Jika tidak segera diatasi dan diantisipasi, gangguan ini akan semakin menakan korbannya hingga pada tingkatan yang membahayakan, yaitu psikosis; sebuah penyakit mental yang tergolong berat. Oleh karena itu, mengenal depresi berikut gejala dan resiko yang ditimbulkan serta upaya menanggulanginya menjadi sangat penting.
\end{abstract}

Kata kunci: Depresi, resiko, menanggulangan

\section{A. Pengertian Depresi Mental}

Istilah depresi sudah sangat populer dalam masyarakat dan semua orang mengetahuinya. Akan tetapi, arti sebenarnya dari depresi itu sukar didefinisikan secara tepat. Istilah dan kata yang identik maknanya dengan depresi dalam bahasa Indonesia sehari-hari tidak ada. "Sedih" tidak identik dengan depresi demikian juga dengan "putus asa", meski keduanya merupakan gejala penting dari depresi. Orang awam menggunakan istilah depresi dengan sangat bebas dan umum sehingga mengaburkan makna dari istilah depresi itu sendiri.
Istilah depresi pertama kali dikenalkan oleh Meyer (dalam Namora: 1905) untuk menggambarkan suatu penyakit jiwa dengan gejala utama sedih, yang disertai gejalagejala psikologis lainnya, gangguan somatik (fisik) maupun gangguan psikomotor dalam kurun waktu tertentu dan digolongkan ke dalam gangguan afektif.

Depresi merupakan gangguan mental yang sering terjadi di tengah masyarakat. Berawal dari stres yang tidak diatasi, maka seseorang bisa jatuh ke fase depresi. Penyakit ini kerap diabaikan karna dianggap bisa 
hilang sendiri tanpa pengobatan.

Rathus (dalam Namora: 1991) menyatakan orang yang mengalami depresi umumnya mengalami gangguan yang meliputi keadaan emosi, motivasi, fungsional dan gerakan tingkah laku serta kognisi. Menurut Atkinson (1991) depresi sebagai suatu gangguan mood yang dicirikan tidak ada harapan dan patah hati, ketidakberdayaan yang berlebihan, tidak mampu konsentrasi, tidak punya semangat hidup, selalu tegang dan mencoba bunuh diri.

Dr. Jonatan Trisna menyimpulkan bahwa depresi adalah suatu perasaan sendu atau sedih yang biasanya disertai dengan diperlambatnya gerak dan fungsi tubuh, mulai dari perasaan murung sedikit sampai pada keadaan tak berdaya. Depresi adalah gangguan perasaan (afek) yang ditandai dengan afek disforik (kehilangan kegembiraan/gairah) disertai dengan gejala-gejala lain, seperti gangguan tidur dan menurunnya selera makan.

Depresi adalah gangguang perasaan (mood) yang ditandai dengan kemurungan dan kesedihan yang mendalam dan berkelanjutan sehingga hilangnya kegairahan hidup. Ciri kepribadian depresif:
1. Pemurung, sukar untuk bisa senang, sukar untuk merasa bahagia,

2. Pesimis menghadapi masa depan,

3. Memandang diri rendah,

4. Mudah merasa bersalah dan berdosa,

5. Mudah mengalah,

6. Enggan bicara,

7. Mudah merasa sedih, haru, menangis,

8. Erakan lamban, lemah, lesu, kurang energik,

9. Seringkali mengeluh sakit ini dan itu,

10. Mudah tegang, gelisah,

11. Serba cemas, khawatir, takut,

12. Tidak ada kepercayaan diri,

13. Suka menarik diri, pemalu, pendiam,

14. Tidak ada kepercayaan diri, dll.

Menurut I Gusti Ayu Endah Ardjana (dalam Soetjiningsih, 2004) depresi yang nyata menunjukkan trias gejala, yaitu: Pertama, Tertekannya perasaan. Tertekannya perasaan dapat dirasakan penderita, dilaporkan secara verbal, dapat pula diekspresikan dalam bentuk roman muka yang sedih, tidak mengindahkan dirinya, mudah menangis dan sebagainya.

Kedua, Kesulitan berpikir. Kesulitan berpikir nampak dalam 
reaksi verbalnya yang lambat, sedikit sekali bicara dan penderita menyatakan dengan tegas bahwa proses berpikirnya menjadi lambat. Ketiga, Kelambatan psikomotor merupakan gejala yang dapat dinilai secara obyektif oleh pengamat dan juga dirasakan oleh penderita. Misalnya mudah lelah, kurang antusias, kurang energi, ragu-ragu, keluhan somatik yang yang tak menentu.

Depresi yang nyata dapat dilihat pada anak usia lebih 10 tahun terutama apada usia remaja, di mana superego, kemampuan verbal, kognitif dan kemampuan menyatakan perasaannya sudah berkembang lebih matang sehingga gejala depresi pada usia ini mirip dengan gejala depresi pada orang dewasa. Berdasarkan penelitian, semakin meningkat usia anak maka angka kejadian depresinya makin meningkat.

\section{B. Macam-macam Depresi Mental}

Menurut klasifikasi organisasi kesehatan dunia WHO, depresi berdasarkan tingkat penyakitnya dibagi menjadi:

\section{Depresi Ringan}

Depresi ringan datang dan pergi dengan sendirinya, ditandai dengan hati yang berat, sedih, dan murung.
Gejala depresi muncul selama dua minggu berturut-turut, dan gejala itu bukan karena pengaruh obatobatan ataupun penyakit.

\section{Depresi Sedang}

Pada depresi sedang, mood yang rendah berlangsung terus dan individu mengalami simtom fisik.

\section{Depresi Berat}

Depresi berat dicirikan oleh perasaan tidak berguna atau bersalah serta sering disertai gejala fisik seperti turun berat badan, sakit kepala, hingga tidak enak badan. Penderita depresi berat cenderung untuk menarik diri, tidak peduli pada lingkungan sekitar, serta aktivitas fisik yang terbatas.

Depresi

berdasarkan

karakteristiknya dapat dikelompokkan menjadi tiga macam:

\section{Depresi Akut}

Depresi akut mempunyai ciri-ciri: manifestasi gejala depresi jelas (nyata), ada trauma psikologis berat yang mendadak sebelum timbulnya gejala depresi, lamanya gejala hanya dalam waktu singkat, secara relatif mempunyai adaptasi dan fungsi ego yang baik sebelum sakit dan tidak ada psikopatologi yang berat dalam anggota keluarganya yang terdekat. 
2. Depresi Kronik

Depresi kronik mempunyai ciri-ciri: Ada gangguan dalam penyesuaian diri sosial dan emosional sebelum sakit, biasanya dalam bentuk kepribadian yang kaku, ada riwayat gangguan afektif pada anggota keluarga terdekat.

3. Depresi Terselubung

Gejala depresi tak jelas tetapi menunjukkan gejala lain misalnya; hiperaktif, tingkah laku agresif, psikosomatik, dan sebagainya.

Depresi menurut klasifikasi nosologi:

1. Depresi Psikogenik

Depresi yang disebabkan oleh pengaruh psikologis individu.

Biasanya terjadi akibat adanya kejadian yang dapat membuat seseorang sedih atau stress berat.

2. Depresi Edogenik

depresi ini diturunkan, biasanya timbul tanpa didahului oleh masalah psikologis atau fisik tertentu, tetapi bias juga dicetuskan oleh trauma fisik maupun psikis. Depresi ini disebut juga depresi pada usia lanjut yang timbul pada usia 60-65 tahun pada laki-laki dan 50-60 tahun pada wanita.

3. Depresi Somatogenik

Pada depresi ini dianggap bahwa faktor-faktor jasmani berperan dalam timbulnya depresi, adakalanya disebabkan oleh perubahan-perubahan morfologi dari otak seperti tumor otak, defisiensi mental, dan lain-lain, atau akibat penyakit-penyakit jasmani seperti hepatitis, diabetes mellitus, pada fase penghentian kecanduan narkotika, alcohol dan obat penenang.

Macam-macam depresi menurut Dadang Hawari (2001):

1. Depresi Pasca Kuasa, dimana seseorang yang memiliki jabatan kemudian suatu saat jabatan itu hilang, hilang pula kekuasaan dan kekuatannya, dampaknya adalah terganggunya keseimbangan mental emosional dengan munculnya berbagai keluhan fisik, kecemasan dan depresi.

2. Depresi Neurotik (Gangguan Distimik), suatu gangguan afek (mood) yang menahun dan mencakup gambaran afek (mood) depresif atau hilangnya minat atau rasa senang di dalam semua aktivitas kehidupan yang biasa dilakukan.

3. Depresi Siklotimik, seseoraang yang mengalami gangguan ini paling sedikit dalam kurun waktu dua tahun mengalami gangguan alam perasaan (affect/mood) ini, 
yang mencakup suatu saat yang bersangkutan dalam episode depresif dan pada saat yang lain mengalami episode hipomanik.

4. Depresi Pasca NAZA, sebagaimana yang kita ketahui bahwa penyalahgunaan NAZA dapat mengakibatkan ketagihan dan ketergantungan. Apabila yang bersangkutan menghentikannya, maka ia akan jatuh kedalam kecemasan dan atau depresi. Oleh karena itu ia akan memakai NAZA, semakin lama semakin bertambah takarannya (dosis) dan semakin banyak frekuensi pemakaiannya.

\section{Resiko Yang Ditimbulkan Oleh Depresi Mental}

Adapun resiko yang ditimbulkan oleh depresi adalah:

\section{Bunuh diri}

Sangat sering bagi individu yang mengalami depresi memiliki pikiran untuk bunuh diri. Perasaan kesepian dan ketidakberdayaan adalah faktor yang sangat besar penyebab seseorang melakukan bunuh diri. Orang yang menderita depresi kadang-kadang merasa begitu putus asa sehingga mereka benar-benar mempertimbangkan membunuh dirinya sendiri. Telah diketahui bahwa: a. Orang yang bunuh diri sangat kurang mendapat dukungan sosial.

b. Sekitar $65 \%$ orang yang melakukan bunuh diri pernah memberikan tanda peringatan.

c. $90 \%$ dari pelaku percobaan bunuh diri adalah penderita penyakit kejiwaan.

d. $70 \%$ dari pelaku bunuh diri mengidap depresi.

Berdasarkan data organisasi kesehatan dunia WHO yang dihimpun dari tahun 2005-2007 menyatakan bahwa sedikitnya 50.000 orang Indonesia bunuh diri. Guru Besar Fakultas Kedokteran Universitas Trisakti A Prayitno mengatakan, faktor penyebab orang nekat bunuh diri adalah karena kemiskinanyang terus bertambah, mahalnya biaya sekolah dan kesehatan, serta penggusuran. Semua itu berpotensi meningkatkan depresi akibat bertambahnya beban hidup.

2. Gangguan tidur: Insomnia dan Hypersomnia

Gangguan tidur dan depresi cenderung muncul bersamaan. Setidaknya $80 \%$ dari orang yang menderita depresi mengalami insomnia atau kesulitan tidur. Pada orang yang mengalami depresi, 
mereka tidur dengan cepat, namun sering terbangun pada malam hari. Karena adanya perasaan yang tidak nyaman dan tidak rileks, sehingga merasa lelah setelah bangun. Hipersomnia adalah perasaan ngantuk berlebihan meskipun sudah tidur.

3. Gangguan dalam pekerjaan

Pengaruh depresi sangat terasa dalam kehidupan pekerjaan seseorang. Depresi meningkatkan kemungkinan dipecat dan pendapatan yang lebih rendah. Depresi mengakibatkan kerugian dalam produksi karena performa yang sangat buruk. Penurunan pada performa pekerjaan yang terus-menerus ditambah dengan masalah-masalah hubungan di tempat kerja menyebabkan seseorang yang depresi lebih cenderung dipecat dan menjadi pengangguran, menjadi pengangguran dapat menciptakan depresi yang lebih berat.

4. Gangguan pola makan Pada orang yang menderita depresi terdapat dua kecenderungan umum mengenai pola makan yang secara nyata mempengaruhi berat tubuh yaitu:
a. Anoreksia nervosa, yaitu gangguan pola makan dimana

penderitanya mengalami kekurangan berat badan daripada normal (kurang dari 85 $\%$ berat tubuh yang diharapkan) karena memiliki anggapan dirinya gemuk dan menolak makan walaupun memiliki berat badan di bawah normal. Pada perempuan, anoreksia bisa menyebabkan berhentinya proses menstruasi karena kurangnya pemasukan gizi dari makanan.

b. Bulimia nervosa, yaitu keinginan makan-makanan yang manis bertambah Dari penelitian, tiga dari empat individu yang bulimia terkena depresi. Bulimia nervosa adalah gangguan pola makan dimana penderitanya mengalami binge-eating (makan berlebihan) dan melakukan perilaku kompensasi (sengaja memuntahkan makanan, olahraga berlebihan) sebagai reaksi yang muncul bersamaan dengan binge-eating.

c. Obesitas, Emosi dapat mempengaruhi pola makan dan penambahan berat badan. Banyak orang mengatakan mereka makan lebih banyak ketika cemas atau marah, bukti bahwa stres dan depresi dapat 
memicu pola makan. Obesitas

muncul ketika seseorang mengkonsumsi lebih banyak kalori. Makanan yang dimakan oleh orang yang obesitas cenderung manis dan tinggi lemak.

5. Perilaku-perilaku merusak

Beberapa perilaku yang merusak yang disebabkan depresi:

a. Agresivitas dan Kekerasan. Pada individu yang terkena depresi, perilaku yang ditimbulkan bukan hanya berbentuk kesedihan, namun bisa juga dalam bentuk mudah tersinggung dan agresif. Perilaku agresif lebih cenderung ditunjukkan oleh individu pria yang mengalami depresi. Hal ini karena pengaruh hormone. Jika pada wanita hormon estrogen dan progesterone yang mempengaruhi perilaku, testosterone mempengaruhi perilaku pria. Perilaku menjadi berbahaya dan dapat berakibat melukai orang yang dicintai dan juga diri sendiri. Pada kasus yang ekstrem, agresi yang meningkat dapat menyebabkan tindakan pembunuhan. Namun walaupun lebih banyak agresivitas dilakukan oleh pria, wanita yang depresi juga dapat menyebabkan perilaku agresif yang serius, misalnyabmerusak barangbarang bahkan melukai dan membunuh anaknya sendiri.

b. Penggunaan alkohol dan obatobatan terlarang. Telah diketahui bahwa penggunaan alkohol dan obat-obatan terlarang pada remaja selain karena pengaruh teman, juga motivasi diri sendiri yang disebabkan oleh keadaan depresi sebagai cara untuk mencari pelepasan sementara dari keadaan yang tidak menyenangkan.

c. Merokok. Penelitian menunjukkan bahwa ada hubungan antara emosi negatif yang ditimbulkan oleh depresi dengan frekuensi merokok. Hal ini dikarenakan beberapa zat kimia dari rokok dapat meredakan stres untuk sementara.

\section{Faktor Penyebab Depresi Mental dan Metode Penanggulangannya}

Ada lima faktor yang dapat diketahui sebagai faktor penyebab depresi, yaitu: Pertama, faktor psikologis. depresi disebabkan karena kehilangan obyek cinta, kemudian individu mengadakan introyeksi yang ambivalen dari obyek cinta tersebut 
atau rasa marah diarahkan pada diri sendiri. Kedua, faktor biologis. Faktor ini terdiri atas faktor neuro-kimia dan neuro-endokrin. Ketiga, faktor neuroimunologis. Pada orang dewasa sering ditemukan gangguan dalam bidang imunologis sehingga lebih mudah terjadi infeksi pada susunan syaraf pusat. Keempat, faktor genetik. Depresi bisa disebabkan oleh faktor keturunan. Resiko untuk terjadinya depresi meningkat antara $20-40 \%$ untuk keluarga keturunan pertama. Kelima, faktor psikososial. Anak remaja dalam lingkungan keluarga yang broken home.

Menurut Kartini Kartono (2000), stres yang kronis akan berujung pada depresi jika emosi ini tidak ditangani dengan tepat. Terapi dan obat-obatan menjadi metode penyembuhan paling digemari, namun memodifikasi gaya hidup dan pola pikir juga sangat membantu seseorang mengatasi depresi. Berikut langkah mengatasi emosi agar tidak berujung pada depresi berkepanjangan:

1. Bercerita dan minta orang lain mendengarkan Jika memiliki perasaan tertekan/emosi negatif jangan disimpan dihati. Share, berbagi kepada orang yang tepat, keluarga yang dapat dipercaya atau kepada pemukan agama yang dipercaya dan sesuai keyakinan masing-masing, Cara ini sangat membantu untuk melepas beban emosi negatif yang terus mengganggu. Jika kesulitan untuk bercerita atau berbagi dengan sesama maka52, gunakan surat atau diary. Saat kita mengungkapkan perasaan yang mengganggu kita, secara tidak sadar kita juga sedang mengurai energi negatif yang terjebak didalam tubuh kita dan secara perlahan membuat diri kita menjadi lebih baik.

2. Belajar menerima diri sendiri (Self Acceptance). Jika tidak mampu mengatasi depresi seorang diri dan jika usaha yang dilakukan tidak berhasil, hal terbaik yang bisa dilakukan adalah dengan menerima kekurangan tersebut. Daripada mencoba mengubah hidup dengan paksa, kita harus menerima diri kita, dengan apa yang kita rasakan dan berkonsentrasi pada hal-hal yang kita mampu lakukan. Depresi akan lenyap namun kita tidak bisa memprediksi kapan depresi akan terjadi. Dengan menyadari serta menerima keberadaan saat ini, maka mudah sekali bagi kita untuk terlepas dari belenggu depresi. Inilah solusi mudah dan aman untuk 
mengatasi depresi, dan menerima kenyataan dalam hidup.

3. Giving / Beramal. Ada sebuah teknik ampuh yang dapat membantu mengurangi kondisi berat ini, yaitu dengan beramal. Caranya anda cukup melakukan amal atau sedekah selama 29 hari. Jadi setiap hari memikirkan apa yang akan kita berikan (bukan berupa materi saja, bisa tenaga bahkan perhatian dan senyum). Jadi kita memberikan sesuatu yang terbaik pada orang lain. Tehnik ini juga sangat ampuh untuk mengatasi berbagai kasus Psikosomatis (penyakit karena gangguan emosi). Pada saat melakukan hal ini, maka konsentrasi akan tercurah pada kebaikan untuk orang lain. Dan ini adalah energi positif yang diciptakan dan dilemparkan untuk orang lain. Akibatnya energi yang sama akan terlempar kepada kita berpuluh-puluh kali lebih kuat dari apa yang kita lemparkan. Satu syaratnya memberi dengan niat kebahagiaan bagi si penerima, bukan karena kasihan.

4. Berdoa. Mendekatkan diri pada Yang Maha Esa. Pintunya hati dan kuncinya adalah ikhlas dan doa. Ikhlas pun butuh kemampuan dan kekuatan dari sang Maha Hidup.
Jadi niatkan untuk ikhlas dan berdoalah untuk ikhlas terhadap masalah yang sedang dihadapi. Proses Doa (meminta, meyakini dan mnerima) bukanlah 3 kegiatan terpisah, melainkan kegiatan 3 in 1 pada saat yang sama sekaligus. Sadarlah bahwa dengan bantuan Tuhan, semua menjadi mungkin. Tuhan Maha Pemberi, bukan Maha Pemaksa. la hanya memberi apa yang kita minta. Problemnya adalah umumnya manusia tidak tahu apa yang diminta, niat di dalam doanya tidak jelas atau sering meminta yang tidak diinginkannya. Dalam kondisi ikhlas dan berdoa secara sungguh-sungguh, otak memproduksi hormon serotonin dan endorfin yang menyebabkan seseorang merasa nyaman, tenang dan bahagia. Dampaknya adalah imunitas tubuh meningkat, pembuluh darah terbuka lebar, detak jantung menjadi stabil dan kapasitas indra meningkat. Sehingga perbaikan dari dalam, mulai ditampilkan keluar. Emosi membaik, maka fisik jadi lebih baik dan bugar. 


\section{E. Daftar Pustaka}

Atkinson, R.I., Atkinson, R.C., \& Hilgard,

E.S., 1991, Pengantar Psikologi, Erlangga: Jakarta.

Hawari, Dadang, 2001, Manajemen

stress, cemas, dan depresi,

Fakultas Kedokteran UI: Jakarta.

Kartini Kartono, 2000, Hygienne Mental, Mandar Maju: Bandung.

Namora Lumongga Lubis, 2009, Depresi:

Tinjauan Psikologis, Kencana

Prenada Media: Jakarta. 